\title{
NICORANDIL, A POTENT ADENOSINE TRIPHOSPHATE-SENSITIVE POTASSIUM-CHANNEL OPENER, AMELIORATES LUNG ALLOGRAFT REPERFUSION INJURY
}

Motohiro Yamashita, MD

Ralph A. Schmid, MD

Shozo Fujino, MD

Joel D. Cooper, MD, FRCS(C)

G. Alexander Patterson, MD, FRCS(C)
Background: Lung allograft ischemia-reperfusion injury, characterized by increased pulmonary vascular resistance, pulmonary edema, and hypoxia, is the most frequent cause of early graft failure. Exogenous nitric oxide has been shown to reduce lung allograft reperfusion injury. During hypoxia, the adenosine triphosphate-sensitive potassium channel is an important ionic channel that links the bioenergetic metabolism to membrane excitability. It has been shown to play a critical role in vascular permeability and in activation of neutrophils and their subsequent interaction with vessel wall cellular components. The purpose of this study was to investigate whether nicorandil, a novel nitric oxide generator and adenosine triphosphatesensitive potassium-channel opener, might enhance lung preservation and prevent allograft reperfusion injury. Materials and methods: Fourteen dogs underwent left lung allotransplantation. Donor lungs were flushed with modified Euro-Collins solution and stored for 21 hours at $1^{\circ} \mathrm{C}$. Immediately after transplantation, the contralateral right main pulmonary artery and bronchus were ligated to assess isolated allograft function. Hemodynamics and arterial blood gas analysis (inspired oxygen fraction 1.0) were assessed for 6 hours before the dogs were put to death. After the assessment, activity of allograft myeloperoxidase and protein levels of bronchoalveolar lavage fluid were measured. Control animals (group I, $n=$ 5) received no nicorandil. In group II $(n=5)$, the donor lung received nicorandil (24 $\mathrm{mg} / \mathrm{L}$ ) in the flush solution. In addition, recipient animals received nicorandil $(0.5 \mathrm{mg} / \mathrm{kg}$, intravenously) just before reperfusion, as well as a continuous infusion $(0.74 \pm 0.03 \mathrm{mg} / \mathrm{kg}$ per hour) during the 6-hour assessment period. In group III $(n=4)$, glibenclamide, a selective adenosine triphosphate-sensitive potassium-channel blocker, was administered 15 minutes before nicorandil administration to both donor and recipient. The animals in group III received nicorandil in the same regimen as group II. Result: Superior gas exchange and hemodynamics were observed in lungs receiving only nicorandil. Allograft myeloperoxidase activity and protein levels in bronchoalveolar lavage fluid were significantly reduced in group II. Glibenclamide eliminated the beneficial effects of nicorandil. Conclusions: Nicorandil administration in the flush solution and during the reperfusion period ameliorates lung allograft dysfunction, improves blood flow, and reduces pulmonary vascular resistance and myeloperoxidase activity in the transplanted lung. The present study suggests that nicorandil reduces lung allograft reperfusion injury. The
From the Division of Cardiothoracic Surgery, Department of Surgery, Washington University School of Medicine, Barnes Hospital, St. Louis, Mo.

Supported by National Institutes of Health grant 1 R01 HL41281 and a grant from Chugai Pharmaceutical Co., Ltd.

Read at the Seventy-sixth Annual Meeting of The American Association for Thoracic Surgery, San Dicgo, Calif., April 28-May 1, 1996.

Received for publication May 6, 1996; revisions requested May
20, 1996; revisions received June 12, 1996; accepted for publication June 13, 1996.

Address for reprints: G. Alexander Patterson, MD, Division of Cardiothoracic Surgery, Washington University School of Medicine, 3108 Queeny Tower, One Barnes Hospital Plaza, St. Louis, MO 63110.

J Thorac Cardiovasc Surg 1996;112:1307-14

Copyright (C) 1996 by Mosby-Year Book, Inc.

$0022-5223 / 96 \$ 5.00+0 \quad \mathbf{1 2 / 6 / 7 5 8 9 4}$ 


\section{beneficial effects of nicorandil may be attributed to its properties as an adenosine triphosphate-sensitive potassium-channel opener. ( $J$ Thorac Cardiovasc Surg 1996;112:1307-14)}

$S^{\mathrm{c}}$ erious allograft dysfunction occurs in $10 \%$ to $20 \%$ of clinical lung transplants. ${ }^{1,2}$ It remains an unpredictable and major clinical problem during the early postoperative period. Lung allograft reperfusion injury is characterized by poor gas exchange caused by pulmonary edema subsequent to increased pulmonary vascular resistance (PVR) and pulmonary permeability. A number of strategies relating to preservation temperature, ${ }^{3}$ state of inflation, ${ }^{4}$ and administration of various compounds at the time of harvest or reperfu$\operatorname{sion}^{5-7}$ have been shown to reduce lung allograft dysfunction after prolonged preservation. There is evidence that, similar to reperfusion injury in other organs, lung allograft reperfusion injury is neutrophil mediated. Although free radical-mediated endothelial injury is probable, the mechanism of this neutrophilmediated injury is unclear. ${ }^{8}$

Nicorandil, a nicotinamide nitrate with adenosine triphosphate-sensitive potassium $\left(\mathrm{K}_{\mathrm{ATP}}\right)$ channel opener activity, ${ }^{9}$ has been shown to protect against ischemia-reperfusion injury in a variety of experimental models and species. ${ }^{10-12}$ The $K_{\text {ATP }}$ channel is activated during hypoxia. ${ }^{13}$ Hypoxia-induced activation of the $\mathrm{K}_{\mathrm{ATP}}$ channel causes membrane hyperpolarization that results in decreased intracellular $\mathrm{Ca}^{++}$ concentration $^{11}$ and maintains cellular ATP. ${ }^{10,13}$ $\mathrm{K}_{\mathrm{ATP}}$-channel openers have been shown to have other effects, such as suppression of superoxide anion production $^{12}$ and tumor necrosis factor- $\alpha$ production. ${ }^{14}$ In addition to its effect on the $\mathrm{K}_{\mathrm{ATP}}$ channel, nicorandil, as a nitrate, also acts as a potent nitric oxide donor. ${ }^{15}$ We have shown that exogenous nitric oxide ${ }^{2,6}$ or nitric oxide donors ${ }^{5,16}$ improve posttransplantation function of preserved lung allografts.

The aim of the present study was to investigate whether nicorandil, as a $\mathrm{K}_{\mathrm{ATP}}$-channel opener and nitric oxide donor, would reduce ischemia-reperfusion lung injury under conditions similar to those in human lung transplantation. Additionally, we sought to determine whether any beneficial effect of nicorandil on canine lung allografts was due to a $\mathrm{K}_{\mathrm{ATP}}$-channel opener effect or due to the effect of nicorandil as a nitric oxide donor.

\section{Materials and methods}

Fourteen weight-matched pairs of adult mongrel dogs were used. All animals received humane care in compli- ance with the "Principles of Laboratory Animal Care" formulated by the National Society for Medical Research and the "Guide for the Care and Use of Laboratory Animals" prepared by the National Academy of Sciences and published by the National Institutes of Health (NIH publication No. 85-23, revised 1985).

Donor procedure. Harvest and left lung transplantation were performed as previously described. ${ }^{5}$ In brief, donor animals were anesthetized with thiopental sodium given intravenously $(10 \mathrm{mg} / \mathrm{kg})$ and then by atropine $(0.5 \mathrm{mg})$ and were intubated with a $9 \mathrm{~F}$ endotracheal tube. The lungs were ventilated (Bennett MA1; Puritan-Bennett Corp., Overland Park, Kan.) with $100 \%$ oxygen at a tidal volume of $550 \mathrm{ml}$ at a rate of 15 breaths $/ \mathrm{min}$ and at a positive end-expiratory pressure of $5 \mathrm{~cm} \mathrm{H}_{2} \mathrm{O}$. After a median sternotomy, the superior and inferior venae cavae, the ascending aorta, the trunks of the pulmonary artery, and the trachea were isolated. Animals were given heparin $(400 \mathrm{U} / \mathrm{kg}$ ) before insertion of a curved metal-tipped cannula (3M Health Care Cardiovascular Systems, Ann Arbor, Mich.) through a purse-string suture in the main pulmonary artery just distal to the pulmonary valve. Before pulmonary artery flush, prostaglandin $\mathrm{E}_{1}\left(\mathrm{PGE}_{1}\right.$, $250 \mu \mathrm{g}$ ) (Prostin VR Pediatric; The Upjohn Company, Kalamazoo, Mich.) was injected directly into the pulmonary artery. Cardiac inflow was occluded by ligation of the superior and inferior venae cavae 20 seconds after the infusion of $P G E_{1}$. The proximal inferior venae cava was cut and the left atrial appendage was amputated for decompression of the pulmonary artery flush. The lungs were perfused immediately, at a pressure of $40 \mathrm{~cm} \mathrm{H}_{2} \mathrm{O}$, with $1500 \mathrm{ml}$ of cold $\left(4^{\circ} \mathrm{C}\right)$ modified Euro-Collins solution. During the flush the lungs were cooled topically by flooding the thoracic cavity with cold $\left(1^{\circ} \mathrm{C}\right)$ saline solution. The flushing pressure was monitored through a transducer between the flushing tube and the pulmonary artery cannula. When the flushing was completed, the trachea was clamped at end-inspiration (tidal volume 550 $\mathrm{ml}$ ) and the heart-lung block was excised. The harvested organs were stored in modified Euro-Collins solution $\left(1^{\circ} \mathrm{C}\right)$ for 21 hours before implantation.

Recipient procedure. Left single lung transplantation was performed as previously described. ${ }^{5}$ Recipient animals were anesthetized in the same manner as the donor animals and their lungs were ventilated with an adjustable-rate Harvard pump respirator (model 613; Harvard Apparatus Co., Inc., South Natik, Mass.) with $98.5 \%$ oxygen and $1.5 \%$ halothane. A femoral arterial line and a thermodilution catheter were placed and continuously transduced (model 1290A, Hewlett-Packard Company, Andover, Mass.). After left pneumonectomy, the contralateral main pulmonary artery and upper and intermediate bronchi were mobilized and encircled separately. The donor left lung was separated from the heart-lung block and left single lung allotransplantation was performed by standard techniques. ${ }^{5}$ The allograft was topi- 
cally cooled with iced slush during implantation. Left atrial anastomosis was performed first with a continuous everting mattress suture. The pulmonary artery and the bronchus were anastomosed by a continuous over-andover suture. After reperfusion of the allograft, a Millar pressure transducer (Millar Instruments, Inc., Houston, Tex.) was placed in the left atrium and two chest tubes were inserted. The contralateral bronchi and pulmonary artery were ligated. At this point ventilation was changed to 15 breaths $/ \mathrm{min}$ at a tidal volume of $550 \mathrm{ml}$ and a positive end-expiratory pressure of $5 \mathrm{~cm} \mathrm{H}_{2} \mathrm{O}$ (Bennett MA1). This ventilator change was required to maintain precise levels of inspired oxygen and positive end-expiratory pressure during the subsequent assessment period. The chest was closed in layers with absorbable sutures. Animals were turned to the supine position for the 6-hour assessment period.

Study groups. In group I (control, $n=5$ ), donor lungs were flushed as described earlier and nicorandil was not administered. In group II $(n=5)$, nicorandil $(24 \mathrm{mg} / \mathrm{L})$ was added to the flush solution described earlier. Recipients were also given nicorandil $(0.5 \mathrm{mg} / \mathrm{kg}$, intravenous bolus) immediately before reperfusion and continuously $(0.74 \pm 0.03 \mathrm{mg} / \mathrm{kg}$ per hour) with a syringe pump (model 355, Orion Research Inc., Boston, Mass.) during the 6-hour assessment period. In group III $(n=4)$, donors received glibenclamide (a specific $\mathrm{K}_{\mathrm{ATP}}$-channel blocker) (Sigma Chemical Company, St. Louis, Mo.), administered at a dose of $3 \mathrm{mg} / \mathrm{kg}$ intravenously 15 minutes before donor lung flush. For this study glibenclamide was dissolved in dimethyl sulfoxide 2 hours before use. Recipient animals in group III also received the same nicorandil regimen as group II. Glibenclamide $(1.0 \mathrm{mg} / \mathrm{kg}$ bolus given intravenously) was administered 15 minutes before the nicorandil bolus. Group III recipients also received intermittent glibenclamide administration $(0.5 \mathrm{mg} / \mathrm{kg}$ bolus given intravenously) every 90 minutes during the 6-hour assessment period (Table I). Corticosteroids were not administered to donors or recipients.

Assessment of lung function. Anesthesia was maintained with intravenous administration of sodium thiopental. Cardiac output was measured hourly (model 9520, Baxter Healthcare Corporation, Edwards Div., Santa Ana, Calif.). Aortic, pulmonary artery, central venous, and left atrial pressure were monitored continuously, and arterial and mixed venous blood gases were assessed every 15 minutes during the 6-hour assessment period. Sodium bicarbonate was infused intravenously as necessary to maintain $\mathrm{pH}$ level. Intravenous Ringer's lactate solution was administered to keep central venous pressure within baseline $\pm 2 \mathrm{~mm} \mathrm{Hg}$.

After the final measurement, the animals were put to death by overdose of sodium thiopental and intravenous administration of potassium chloride $20 \mathrm{mEq}$. Samples of transplanted lungs were obtained for tissue myeloperoxidase (MPO) assay and bronchoalveolar lavage fluid (BALF) study.

BALF analysis. Immediately after death, left lingular segments were obtained for use in the BALF study. Fifty milliliters of saline solution was injected slowly through the lingular bronchus and BALF was collected by gravity. This procedure was repeated twice, so that the segment was washed with a total of $100 \mathrm{ml}$ saline solution. The
Table I. Classification of study groups

\begin{tabular}{lll}
\hline & \multicolumn{1}{c}{ Donor } & \multicolumn{1}{c}{ Recipient } \\
\hline Group I & No nicorandil & No nicorandil \\
Group II & Nicorandil $(24 \mathrm{mg} / \mathrm{L})$ in & Nicorandil $(0.5 \mathrm{mg} / \mathrm{kg})$ \\
& flush solution & bolus IV + continuous \\
& & $0.74 \mathrm{mg} / \mathrm{kg}$ per hour \\
Group III & Glibenclamide $(3 \mathrm{mg} / \mathrm{kg})$ & Glibenclamide $(3 \mathrm{mg} / \mathrm{kg})$ \\
& IV + nicorandil $(24$ & $\mathrm{IV}+$ nicorandil $(0.5$ \\
& $\mathrm{mg} / \mathrm{L})$ in flush solution & $\mathrm{mg} / \mathrm{kg})$ bolus IV + \\
& & continuous $0.74 \mathrm{mg} / \mathrm{kg}$ \\
& & per hour
\end{tabular}

$I V$, Intravenous.

BALF was centrifuged at $400 \mathrm{~g}$ to separate the supernatant and cell pellet. One milliliter of the supernatant was reserved to measure the concentration of protein by the method of Pierce Laboratories. ${ }^{18}$

MPO assay. Recipient lung samples were frozen immediately by immersion in dichlorodifluromethane $\left(\mathrm{CCl}_{2} \mathrm{~F}_{2}\right)$ that had been precooled to the freezing point and stored at $-70^{\circ} \mathrm{C}$ until assay. Quantitative MPO activity was determined as previously described. ${ }^{8}$ Frozen lung tissue $(100 \mathrm{mg})$ was homogenized in $1 \mathrm{ml}$ of $0.5 \%$ hexadecyl-trimethylammonium bromide, $5 \mathrm{mmol} / \mathrm{L}$ ethylenediaminetetraacetic acid, and $50 \mathrm{mmol} / \mathrm{L}$ potassium phosphate buffer $(\mathrm{pH}$ 6.2) with a Broeck tissue grinder (Kontes Glass Co., Vineland, N.J.) to release MPO from the primary granules of the polymorphonuclear leukocytes. The homogenate was centrifuged at $10,000 \mathrm{~g}$ for 15 minutes at $4^{\circ} \mathrm{C}$. The supernatant was assayed for MPO activity and total soluble protein by the method of Pierce Laboratories. ${ }^{18}$ Enzyme activity was measured spectrophotometrically: $10 \mu \mathrm{l}$ of tenfold dilute supernatant was combined with $0.6 \mathrm{ml}$ Hanks bovine serum albumin $(0.25 \%$ bovine serum albumin added to Hanks solution), $0.5 \mathrm{ml}$ of $100 \mathrm{mmol} / \mathrm{L}$ potassium phosphate buffer (pH 6.2), $0.1 \mathrm{ml} 0.05 \%$ hydrogen peroxide, and $0.1 \mathrm{ml}$ of 1.25 $\mathrm{mg} / \mathrm{ml}$ o-dianisidine. Color development was stopped by addition of $0.1 \mathrm{ml}$ of $1 \% \mathrm{NaN}_{3}$ after 5 and 20 minutes at room temperature. The optical density was measured at 460 $\mathrm{nm}$ with a spectrophotometer (PMQ II, Carl Zeiss, Oberkochen, Germany). The color development from 5 minutes to 20 minutes was linear. Enzyme activity was defined as the amount of MPO that produced an absorbance change of 1.0 optical density unit per minute per milligram of tissue protein at room temperature $(\Delta \mathrm{OD} / \mathrm{min} / \mathrm{mg})$.

Statistical analysis. All data are presented as the mean \pm the standard error of the mean. Comparisons between groups were made by one-way analysis of variance followed by Scheffe's test for multiple comparisons. In addition, analysis of variance with repeated measures was used to compare an overall difference of hemodynamics and blood gas data between groups. Differences were considered significant when the $p$ value was less than 0.05 .

\section{Results}

There were no significant differences among groups with respect to donor weight, recipient weight, flushing times and pressure, preservation time, and warm ischemic time (Table II). 

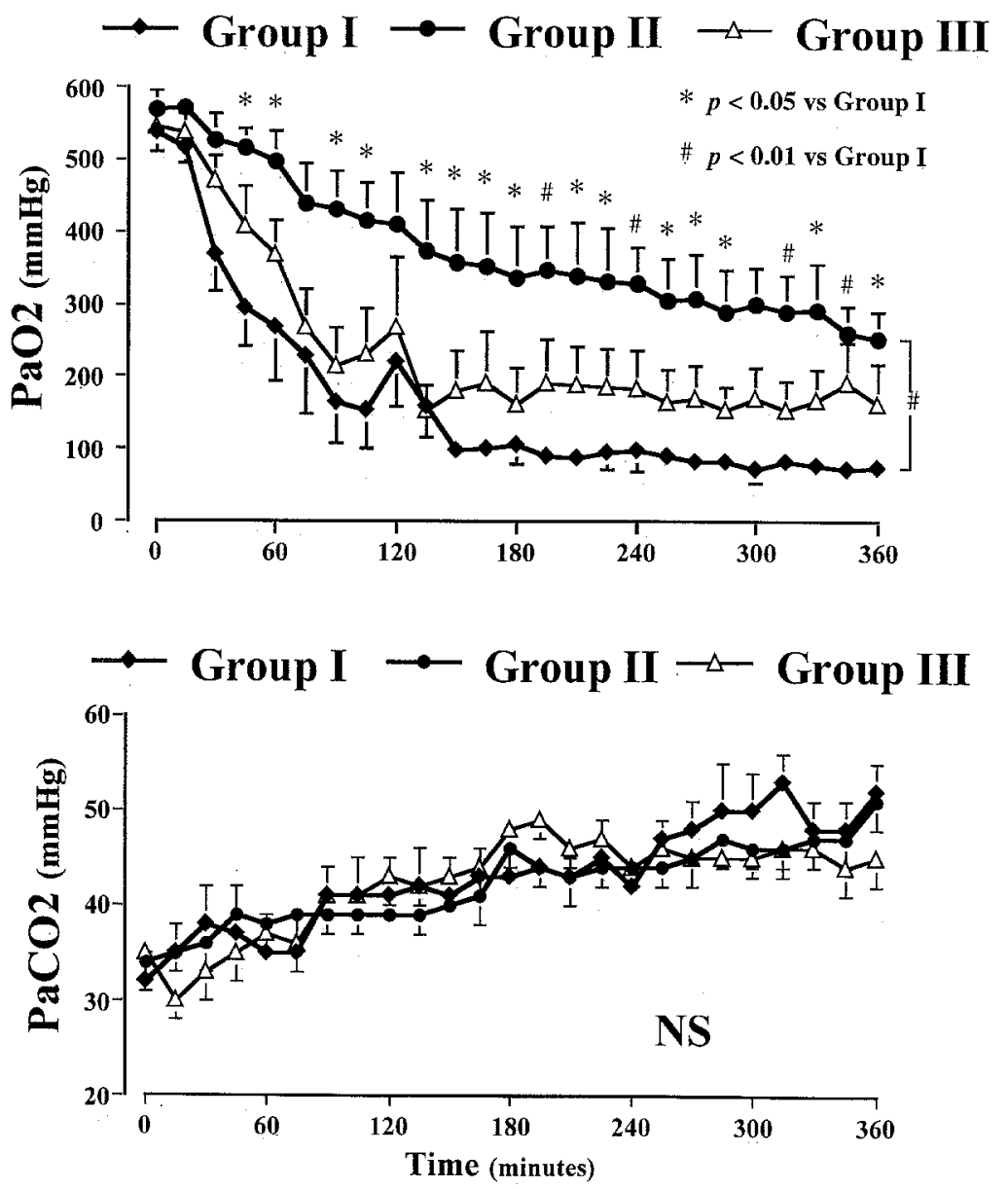

Fig. 1. Arterial oxygen tension $\left(\mathrm{PaO}_{2}\right)$ and arterial carbon dioxide tension $\left(\mathrm{PaCO}_{2}\right)$ for groups $\mathrm{I}, \mathrm{II}$, and III through the 6-hour assessment. There was significant difference in $\mathrm{PaO}_{2}(p<0.01)$ between groups I and II, but there were no significant differences in $\mathrm{PaCO}_{2}$ among the three groups. NS, Not significant.

Table II. Characteristics of experimental groups

\begin{tabular}{lcccccc}
\hline & $\begin{array}{c}\text { Donor } \\
\text { weight } \\
(\mathrm{kg})\end{array}$ & $\begin{array}{c}\text { Recipient } \\
\text { weight } \\
(\mathrm{kg})\end{array}$ & $\begin{array}{c}\text { Flush } \\
\text { time } \\
(\mathrm{sec})\end{array}$ & $\begin{array}{c}\text { Flush } \\
\text { pressure } \\
(\text { mmHg) }\end{array}$ & $\begin{array}{c}\text { Storage } \\
\text { time } \\
\text { (hour: min) }\end{array}$ & $\begin{array}{c}\text { Warm } \\
\text { ischemic } \\
\text { time (min) }\end{array}$ \\
\hline Group I $(n=5)$ & $26.9 \pm 0.6$ & $27.8 \pm 0.4$ & $87 \pm 7$ & $18.8 \pm 1.1$ & $21: 07 \pm 4$ & $80 \pm 4$ \\
Group II $(n=5)$ & $27.1 \pm 0.8$ & $28.5 \pm 0.8$ & $80 \pm 3$ & $17.6 \pm 1.5$ & $20: 55 \pm 5$ & $72 \pm 3$ \\
Group III $(n=4)$ & $26.7 \pm 0.8$ & $27.4 \pm 0.9$ & $88 \pm 5$ & $18.5 \pm 0.9$ & $21: 01 \pm 7$ & $75 \pm 5$ \\
\hline
\end{tabular}

Storage time, Period from inflow occlusion to perfusion; warm ischemic time, period from inflow occlusion to storage in ice + period from implantation to reperfusion.

Gas exchange. Throughout the 6-hour assessment, oxygenation in group II animals was superior to that in group I ( $p<0.01$ ) (Fig. 1). During the first 45 minutes of reperfusion, there was no statistically significant difference among the three groups, but gas exchange deteriorated rapidly in groups I and III. There were significant differences in mean arterial oxygen tension after 60 minutes of initial assessment. Arterial oxygen tension in groups I, II, and III after 360 minutes of assessment were $74 \pm 6,252 \pm 36$ ( $p<0.01$ vs group I), and $162 \pm 68 \mathrm{~mm} \mathrm{Hg}$, respectively. Arterial carbon dioxide tension was not different among the groups. 

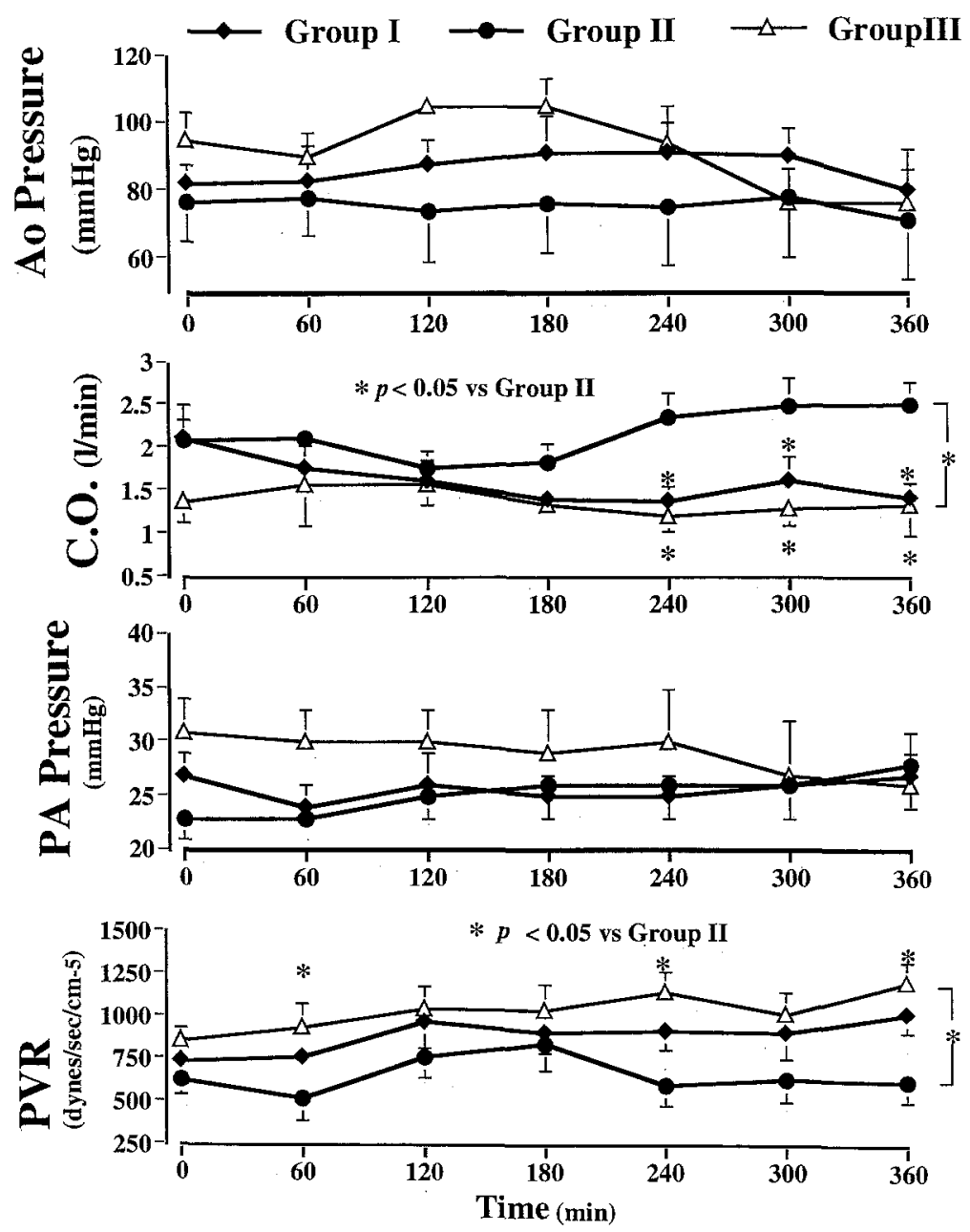

Fig. 2. Hemodynamic data during the 6-hour assessment. There were no statistical differences in mean aortic pressure $(A O P)$ and mean pulmonary pressure among the three groups over time. Cardiac output (C.O.) in group II was higher than in groups I and III $(p<0.05)$ over time. Pulmonary vascular resistance $(P V R)$ in group III was higher than in group II $(p<0.05)$ over time.

Hemodynamics. There were no statistically significant differences in mean aortic pressure and mean pulmonary artery pressure among groups. Cardiac output in group II was higher than that in group I $(p<$ 0.05 ) after 240 minutes and 360 minutes of assessment, respectively, and cardiac output in group II was significantly higher than in group III over time $(p<0.05)$. PVR in group III was higher than in group II $(p<$ 0.05 ) after 60,240 , and 360 minutes of assessment, and PVR in group I was higher than in group II $(p<0.05)$ after 360 minutes of assessment. During the assessment period PVR in group III was significantly higher than in group II over time $(p<0.05)$ (Fig. 2).

Myeloperoxidase assay. MPO activity in the transplanted lungs of group II was significantly lower than in groups I and III (groups I, II and III: $0.40 \pm 0.02,0.30 \pm 0.03$, and $0.38 \pm 0.05 \Delta \mathrm{OD} / \mathrm{mg}$ per minute $p<0.05$ vs group I) (Fig. 3).

BALF protein study. BALF protein levels in group II were lower than in the other groups. (levels in groups I, II, and III were $5.4 \pm 1.0,2.2 \pm 0.3[p<$ $0.05]$, and $5.7 \pm 0.7 \mathrm{mg} / \mathrm{ml}$, respectively) (Fig. 4). However, there was no significant difference in total amount of BALF among the three groups (700 \pm $110,500 \pm 160$, and $710 \pm 110 \mathrm{ml}$, respectively).

\section{Discussion}

Although a large number of strategies have been shown to reduce ischemia-reperfusion injury in various organs, the exact pathophysiologic mechanisms 


\section{MPO in Allografts}

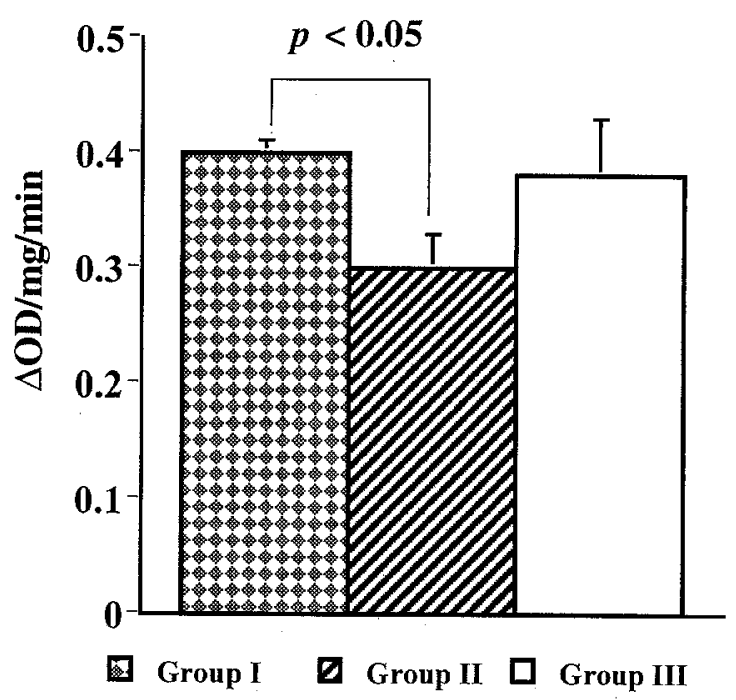

Fig. 3. Tissue MPO activity after the 6-hour assessment. MPO activity in group II was significantly lower than in groups I and III $(p<0.05)$.

remain unclear. However, it has been demonstrated that endothelial dysfunction, ${ }^{16,19}$ neutrophil activation, ${ }^{11,20}$ oxygen-derived free radicals, ${ }^{8,20}$ platelet activation, ${ }^{22}$ and various cytokines ${ }^{23}$ are involved in ischemia-reperfusion injury. Recently the interaction between endothelium and neutrophil activation has been shown to play an important role in lung allograft ischemia-reperfusion injury. ${ }^{5,7}$

The $\mathrm{K}_{\mathrm{ATP}}$-channel is an important ionic channel that links cellular bioenergic metabolism to membrane excitability. ${ }^{9} \mathrm{~K}_{\text {ATP }}$ channels are well represented in vascular endothelium, smooth muscle, skeletal muscle, endocrine cells, neurons, and cardiomyocytes. ${ }^{11}$ These channels are activated by adenosine diphosphate, guanosine diphosphate, and acidic intracellular $\mathrm{pH} .{ }^{9}$ They are blocked by ATP and antidiabetic sulfonylureas such as glibenclamide. The adenosine triphosphate/diphosphate ratio is thought to be an essential regulatory factor for $\mathrm{K}_{\mathrm{ATP}}$-channels. ${ }^{24}$. During hypoxia, $\mathrm{K}_{\mathrm{ATP}}$ channels are activated. This activation results in increased $\mathrm{K}^{+}$conductance or $\mathrm{K}^{+}$efflux, hyperpolarization of the cellular membrane, with subsequent reduction of calcium $\left(\mathrm{Ca}^{++}\right)$influx into the cell and $\mathrm{Ca}^{++}$release from sarcoplasmic reticulum (Table III). ${ }^{9}$ Because this massive $\mathrm{Ca}^{++}$entry is not compensated for by $\mathrm{Ca}^{++}$efflux during ischemic conditions, hypoxia is thought to increase cytosolic free

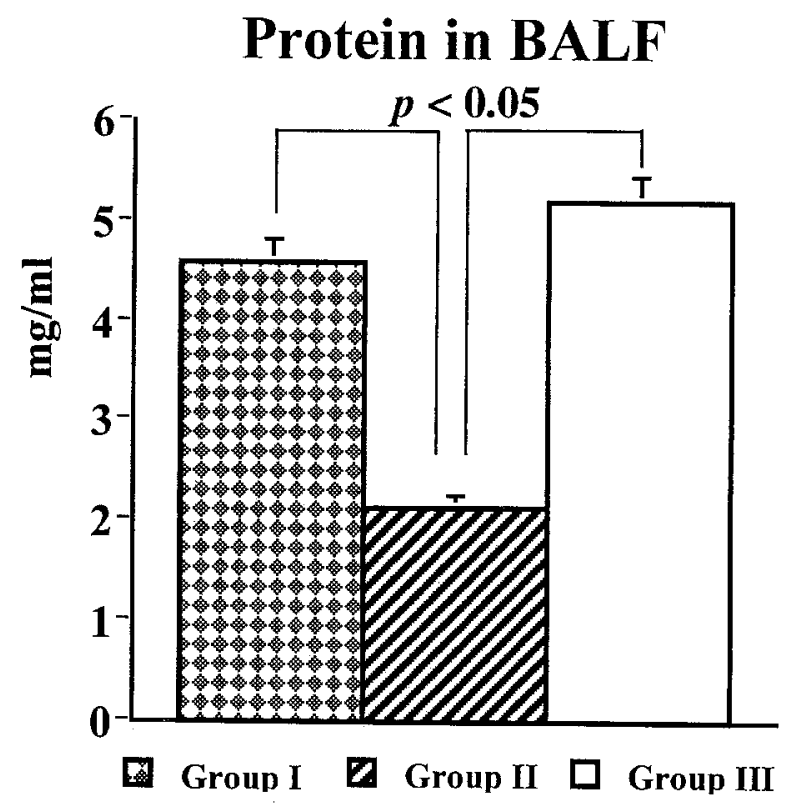

Fig. 4. Results of BALF protein level after the assessment period. BALF protein concentration from allograft in group II was significantly lower than in group I $(p<$ $0.05)$.

$\mathrm{Ca}^{++}$concentration and finally lead to cell death. ${ }^{9}$ So that this harmful cascade can be prevented, $\mathrm{K}_{\mathrm{ATP}}$ channels are opened during early hypoxia by depletion of intracellular ATP. This results in a form of cellular energy maintenance as evidenced by reduced contractility of cardiomyocytes ${ }^{12,15}$ and vascular smooth muscle ${ }^{10,15}$ and decrease of superoxide anion production in neutrophils. ${ }^{12}$

Nicorandil, $N$-[2-hydroxyethyl] nicotinamide nitrate ester, has been approved for clinical use in ischemic heart disease in Japan because it shares the pharmacologic properties of nitrates and $\mathrm{K}_{\mathrm{ATP}^{-}}$ channel openers. ${ }^{25}$ Several studies in ischemic heart models suggested nicorandil had direct and indirect myocardial protective effects. ${ }^{12,26}$ The present study demonstrated that nicorandil improves gas exchange in preserved canine lung allografts. However it is not easy to discriminate its beneficial effects as a nitric oxide donor and $\mathrm{K}_{\mathrm{ATP}}$-channel opener.

$K_{\mathrm{ATP}}$-channel openers have various physiologic effects derived from increase of $\mathrm{K}^{+}$efflux and inhibition of cytosolic free $\mathrm{Ca}^{++}$accumulation. ${ }^{27}$ The first is an oxygen-sparing effect. ${ }^{24}$ Klein and associates ${ }^{10}$ demonstrated in a pig ischemia-reperfusion study that nicorandil increased coronary blood flow like a nitroglycerin; unlike nitroglycerin, however, nicorandil increased coronary venous oxy- 
Table III. Mechanism of $K_{A T P^{-}}$-channel opener

$$
\begin{gathered}
\text { Increased } \mathrm{K}^{+} \text {permeability } \\
\text { Hyperpolarization of cell membrane } \\
\text { Closure of } \mathrm{Ca}^{2+} \text { channels } \\
\text { Reduction of free intracellular } \mathrm{Ca}^{2+}
\end{gathered}
$$

gen saturation and substantially decreased regional oxygen consumption.

Second, opening the $\mathrm{K}_{\mathrm{ATP}}$-channel has a vasodilatory effect and plays a role in the regulation of blood flow not only by direct vascular smooth muscle dilatation but also by endothelial nitric oxide synthesis. ${ }^{11,26,28}$ Janigro and associates ${ }^{11}$ demonstrated in their in vitro study that $\mathrm{K}_{\mathrm{ATP}}$-channels could modify the permeability of the blood-brain barrier under pathophysiologic conditions such as ischemia. Interestingly, Khimenko, Moore, and Tay$\operatorname{lor}^{29}$ demonstrated in their isolated perfused rabbit model that activation of the $\mathrm{K}_{\mathrm{ATP}}$ channel could protect against and reverse lung endothelial damage associated with ischemia-reperfusion injury. In the present study, protein levels in BALF, an indicator of pulmonary vascular permeability, were significantly lower in the nicorandil group, but there was no difference in BALF protein levels between the control and glibenclamide groups.

Finally, $\mathrm{K}_{\mathrm{ATP}}$-channel openers inhibit superoxide anion production by neutrophils ${ }^{12}$ and tumor necrosis factor- $\alpha$ production by macrophages. ${ }^{14} \mathrm{We}^{30}$ have previously shown in an in vitro model that superoxide-induced vascular permeability injury occurs during the ischemic phase and dimethyl thiourea reduces the permeability damage.

Although these various $\mathrm{K}_{\mathrm{ATP}}$-channel effects may be important, another potential physiologic mechanism may explain the beneficial effect of nicorandil. Nitric oxide recently has been purported to be an important physiologic regulator of the microcirculation, as well as vascular permeability. ${ }^{14,16,19,20} \mathrm{Ni}$ tric oxide released from endothelial cells maintains vascular homeostatic properties by relaxing vascular smooth muscle, ${ }^{16}$ inhibiting neutrophil adhesion ${ }^{31}$ and platelet aggregation, ${ }^{32}$ and maintaining endothelial barrier properties. ${ }^{19}$ Endogenous, as well as exogenous, nitric oxide stimulates guanosine $3^{\prime}-5^{\prime}$ cyclic monophosphorathiate production and regulates vascular tone. ${ }^{32}$ In recent years, a number of authors have demonstrated the beneficial effects of nitric oxide ${ }^{2,14}$ or nitric oxide donors such as nitro- prusside, ${ }^{7}$ L-arginine, ${ }^{17}$ and nitroglycerin ${ }^{16}$ on human and canine lung allograft reperfusion injury.

In the current study, nicorandil ameliorated pulmonary ischemia-reperfusion injury as demonstrated by high cardiac output, lower PVR, and better gas exchange during the early posttransplantation period. The allografts in group II showed significantly lower MPO and BALF protein levels. When glibenclamide, a $\mathrm{K}_{\mathrm{ATP}}$-channel inhibitor, was administered simultaneously with nicorandil, the beneficial effects of nicorandil were antagonized and the glibenclamide group showed no statistically significant difference from the control group. Although the nitric oxide donor effect of nicorandil cannot be ignored, we believe that the observed improvement in lung allograft reperfusion injury after nicorandil administration is due to its effect on $\mathrm{K}_{\mathrm{ATP}}$ channels.

We thank Mr. Mitsuaki Chujo, Chugai Pharmaceutical Co., Ltd., Tokyo Japan, for his enormous support and the gift of nicorandil. We also thank Jill Manchester for assisting with the myeloperoxidase and protein assays, and Dennis Gordon, Donna Marquart, Timothy Morris, Duaine Probst, and Steve Labarbera for their expert technical assistance, and Mary Ann Kelly and Dawn Schuessler for secretarial support. Statistical advice was obtained from Richard B. Schuessler, PhD.

\section{REFERENCES}

1. Patterson GA, Cooper JD, editors: Lung transplantation. Chest Surg Clin North Am 1993;3.

2. Date H, Triantafillou AN, Trulock EP, Pohl MS, Cooper JD, Patterson GA. Inhaled nitric oxide reduces human lung allograft dysfunction. J Thorac Cardiovasc Surg 1996;111: 913-9.

3. Date H, Lima O, Matsumura A, Tsuji H, Avignon DA, Cooper JD. In a canine model, lung preservation at $10^{\circ} \mathrm{C}$ is superior to that at $4^{\circ} \mathrm{C}$. J Thorac Cardiovasc Surg 1992;103: 773-80.

4. Veith FJ, Shihna SBP, Graves JS, Boley SJ, Dougherty JC. Ischemic tolerance of the lung: the effect of ventilation and inflation. J Thorac Cardiovasc Surg 1992;103:773-80.

5. Yamashita M, Schmid RA, Okabayashi K, Ando K, Kobayashi $\mathbf{J}$, Cooper JD, et al. Pentoxyfilline in flush solution improves early lung allograft function. Ann Thorac Surg 1996;61:1055-61.

6. Okabayashi K, Triantafillou AN, Yamashita M, Aoe M, 
DeMeester SR, Cooper JD, et al. Inhaled nitric oxide improves lung allograft function after prolonged storage. J Thorac Cardiovasc Surg 1996;112:293-9.

7. Egan TM, Karls MD. Effect of a free radical scavenger. Ann Thorac Surg 1993;55:1453-9.

8. Gaboury J, Woodman RC, Granger DN, Reinhardt P, Kubes P. Nitric oxide prevents leukocyte adherence: role of superoxide. Am J Physiol 1993;265:H862-7.

9. Lazdunski M. ATP-sensitive potassium channels: an overview. J Cardiovase Pharmacol 1994;24(suppl 4):S1-S5.

10. Klein HH, Pich S, Lindert-Heimiberg S, Schade-Brittinger C, Maisch B, Nebendahl K. Comparative study on the effects of intracoranary nicorandil and nitroglycerin in ischemic, reperfused porcine hearts. Eur Heart J 1995;16:603-9.

11. Janigro D, West DA, Gorgon EL, Winn HR. ATP-sensitive $\mathrm{K}^{+}$channels in rat aorta and brain microvascular endothelial cells. Am J Physiol 1993;265:C812-21.

12. Gross GJ, Auchampach JA, Maruyama M, Warltier DC, Pierper M. Cardioprotective effects nicorandil. J Cardiovasc Pharmacol 1992;209(suppl 3):S22-28.

13. Noma A. ATP-regulated $\mathrm{K}^{+}$channels in cardiac muscle. Nature 1983;305:147-8.

14. Pogrebniak HW, Matthews W, Pass HI. Alterations in macrophage free radical and tumor necrosis factor production by a potassium channel activator. $J$ Surg Res 1992;52:395-400.

15. Nakae I, Quan L, Hashimoto K, Sugimoto Y, Tsutamoto T, Kinoshita M. Mechanism of vasodilatory action of nicorandil on coronary circulation in dogs. Cardiovasc Drug Ther 1994;8:137-45.

16. Naka Y, Chowdhury NC, Oz MC, Smith CR, Yano OJ, Michler RE, et al. Nitroglycerin maintains graft vascular homeostasis and enhances preservation in an orthotopic rat lung transplant model. J Thorac Cardiovasc Surg 1995;109: 206-11.

17. Normandin L, Herve $P$, 3rink $C$, et al. L-Arginine and pentoxifylline attenuate endothelial dysfunction after lung reperfusion injury in rabbit. Ann Thorac Surg 1995;60:64650 .

18. Smith PK, Krohn RI, Hemanson GT, et al. Measurement of protein using bicinchoninic acid. Anal Biochem 1985;150: 768-85.

19. Kubes P, Granger DN. Nitric oxide modulates microvascular permeability. Am J Physiol 1992;262:H611-5.

20. Kubes P, Suzuki M, Granger DN. Nitric oxide: an endogenous modulator of leukocyte adhesion. Proc Natl Acad Sci U S A 1991;88:323-6.

21. McCord JM. Oxygen-derived free radicals in post ischemic tissue injury. N Engl J Med 1985;312:159-63.

22. Quyami AK, Jamiesan ERE, Poostizadeh A. Effect of platelet-activating factor antagonist CV-3988 in preservation of heart and lung for transplantation. Ann Thorac Surg 1991; 52:1026-32.

23. Mandfil G. ARDS, neutrophils, and pentoxifylline. Am Rev Respir Dis 1988;138:1344-50.

24. Decking UKM, Reffelmann T, Schrader J, Kammermeier H. Hypoxia-induced activation of KATP channels limits energy depletion in the guinea pig heart. Am J Physiol 1995;269: H734-42.

25. Taira N. Nicorandil as a hybrid between nitrates and potassium channel activators. Am J Cardiol 1989;63:18J-24J.
26. Mitani A, Kinoshita K, Fukamachi K, et al. Effects of glibenclamide and nicorandil on cardiac function during ischemia and reperfusion in isolated perfused rat hearts. Am J Physiol 1991;261:H1864-71.

27. Luecckhoff A, Pohi U, Muish A, Busse R. Differential role of extra- and intracellular calcium in the release of EDRF and prostacyclin from cultured endothelial cells. Br J Pharmacol 1988:95:189-96.

28. Ignarro LJ. Nitric oxide: a novel signal transduction mechanism for transcellular communication. Hypertension 1990;16: 477-83.

29. Khimenko PL, Moore TM, Taylor AE. ATP-sensitive $\mathrm{K}^{+}$ channels are not involved in ischemia-reperfusion lung endothelial injury. J Appl Physiol 1995;79:554-9.

30. Haniuda M, Dressler CM, Mizuta T, Cooper JD, Patterson GA. Free radical-mediated vascular injury in lungs preserved at moderate hypothermia. Ann Thorac Surg 1995;60:1376-81.

31. Moncada S, Palmer RMJ, Higgs EA. Nitric oxide: physiology, pathophysiology, and pharmacology. Pharmacol Rev 1991; 43:109-42.

32. Pinsky DJ, Naka Y, Chowdhury NC, et al. The nitric oxide/ cyclic GMP pathway in organ transplantation: critical role in successful lung preservation. Proc Natl Acad Sci U S A 1994;91:12086-90.

\section{Discussion}

Dr. Richard J. Novick (London, Ontario, Canada). Concerning the data on oxygenation during reperfusion, I believe that the beneficial effects are due to both $\mathrm{K}_{\mathrm{ATP}}{ }^{-}$ channel opening and nitric oxide. At the end of 6 hours of reperfusion, the oxygenation is almost the same in group II and group III. You have also shown that MPO is significantly reduced in group II in the graft, which is not primarily due to an effect of $\mathrm{K}_{\mathrm{ATP}}$-channels. I therefore believe that the beneficial results in group II are due to both an effect on potassium channels and a nitric oxide effect.

Dr. Yamashita. I think this nicorandil compound has a nitric oxide effect, so we could see a little bit better results in group II than group III. This group III was also a little bit better than group I. I think this is a nitric oxide effect. This time we cannot see any difference between group III and group II with regard to arterial oxygen tension, but in other parameters we can see a difference. Judging from other parameters, I believe the potassium channel opener effect will affect these other parameters, including a little bit of difference of arterial oxygen tension between group II and group III.

Dr. Joseph M. Arcidi (Maywood, Ill.). You continued the infusion for a time here. We see that oxygenation does continue to decrease over time. Are you investigating whether a longer infusion might maintain oxygenation at a higher level over time?

Dr. Yamashita. In our study case we continued the nicorandil infusion throughout the 6-hour assessment period, but actually I think we do not need to maintain continuous infusion for 6 hours. I think infusing this compound for 2 hours is enough, but I am not sure because I did not examine that point. 